Institute of $\mathbf{F}_{\text {ood and }} \mathbf{A}_{\text {gricultural }} \mathbf{S}_{\text {ciences }}$

\title{
Apple Maggot, Apple Maggot Fly, Rhagoletis pomonella (Walsh) (Insecta: Diptera: Tephritidae) ${ }^{1}$
}

\section{H. V. Weems, Jr. and T. R. Fasulo² \\ Introduction}

The apple maggot, Rhagoletis pomonella (Walsh) (also known as the "railroad worm") is an insect native to North America Originally it fed in the fruit of wild hawthorn (Crataegus spp.), but during the past 130 years it has become a primary pest of cultivated apples, especially in the northeastern United States and southeastern Canada. Summer- and early fall-maturing varieties are particularly vulnerable, but hard winter apples are sometimes infested. Thin skinned sweet and subacid varieties are most susceptible, but acid varieties may be attacked. Plum, pear, and cherries also serve as hosts, but usually the apple maggot is not a serious pest of these fruits. Crab apples are invariably infested by this pest. A closely related species, the blueberry maggot fly (Rhagoletis mendax Curran), is important as a pest of cultivated blueberries.

\section{Synonym}

Trypeta pomonella Walsh

\section{Distribution}

Eastern North Dakota and southern Manitoba to Nova Scotia, southward to eastern Texas to central Florida, occurring over the entire middle and eastern region of the United States. In 1981 it became established in Oregon, from where it spread to California, Washington State, Utah and Colorado, and eventually Nebraska in 1991 (White and Elson-Harris 1994).

\section{Life History and Habits}

Adults emerge from the ground during early summer. Emergence continues for a month or more, and many pupae may remain inactive and not emerge until the second year. Egg-laying usually does not take place until eight to 10 days after the flies have emerged. The female punctures the skin of the fruit with her ovipositor and lays eggs singly in the pulp. Eggs hatch in five to 10 days. The maggots develop slowly in the green fruit and usually do not complete their growth until the infested fruits have dropped

1. This document is EENY-261 (originally published as DPI Entomology Circular 126), one of a series of Featured Creatures from the Entomology and Nematology Department, Florida Cooperative Extension Service, Institute of Food and Agricultural Sciences, University of Florida. Published: January 2002. This document is also available on Featured Creatures Website at http://creatures.ifas.ufl.edu. Please visit the EDIS Website at http://edis.ifas.ufl.edu and the Entomology and Nematology Department website at http://entnemdept.ifas.ufl.edu/.

2. H. V. Weems, Jr., Florida Department of Agriculture and Consumer Services, Division of Plant Industry; and T.R. Fasulo, Department of Entomology and Nematology, Institute of Food and Agricultural Sciences, University of Florida, Gainesville, FL.

The Institute of Food and Agricultural Sciences (IFAS) is an Equal Employment Opportunity - Affirmative Action Employer authorized to provide research, educational information and other services only to individuals and institutions that function without regard to race, creed, color, religion, age, disability, sex, sexual orientation, marital status, national origin, political opinions or affiliations. For information on obtaining other extension publications, contact your county Cooperative Extension Service office. Florida Cooperative Extension Service / Institute of Food and Agricultural Sciences / University of Florida / Larry R. Arrington, Interim Dean 


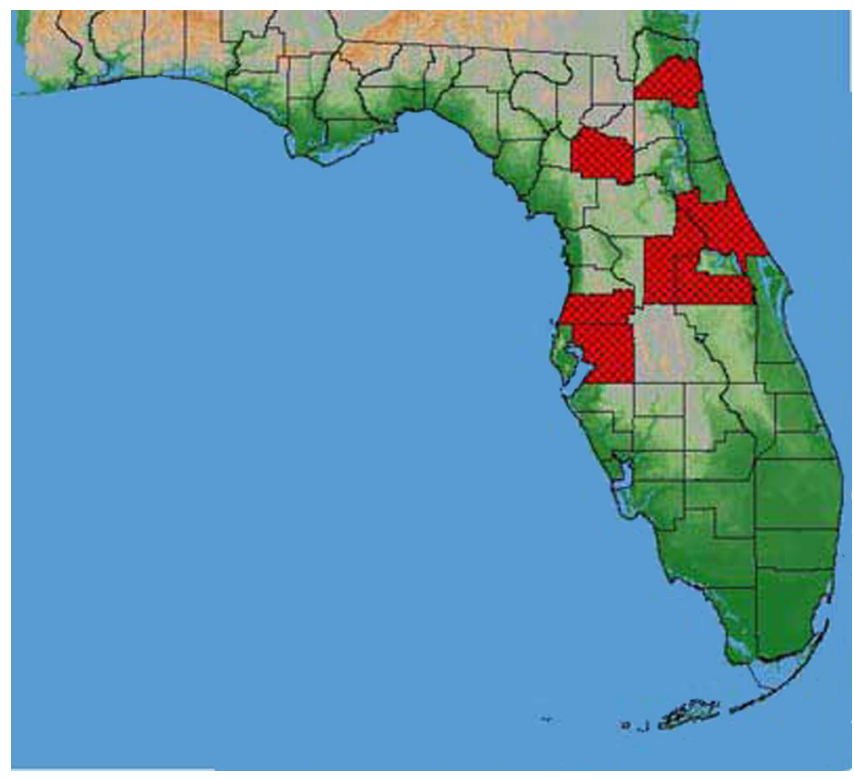

Figure 1. Distribution of the apple maggot fly, Rhagoletis pomonella (Walsh), in Florida. Credits: G.J. Steck and B.D. Sutton, Division of Plant Industry

from the tree, after which growth is completed rapidly.

Larval development requires from two weeks in drops of early maturing apples to three or more months in hard winter varieties. Then the larvae leave the fruit and enter the soil where the puparia are formed. $R$. pomonella undergoes a partial second generation in the southern part of the range, with adults emerging in early fall. Winter is passed as puparia in the soil.

\section{Identification}

Adults of the apple maggot are slightly smaller than a house fly, black in color, with white bands on the abdomen (four on the female and three on the male), and the wings are conspicuously marked with four oblique black bands. Larvae are white or yellowish tapered maggots slightly smaller than those of the house fly. The maggots are about $1 / 2$ inch in length and tapering toward the head. Key characters for the separation of the larval stage from those of related species are given by Phillips (1946).

\section{Hosts}

Apple (Malus spp.), chokeberry (Aronia arbutifolia), crab apple (Malus spp.), cranberry (Vaccinium macrocarpum), dogwood (Cornus florida), hawthorn (Crataegus spp.), plum and cherry

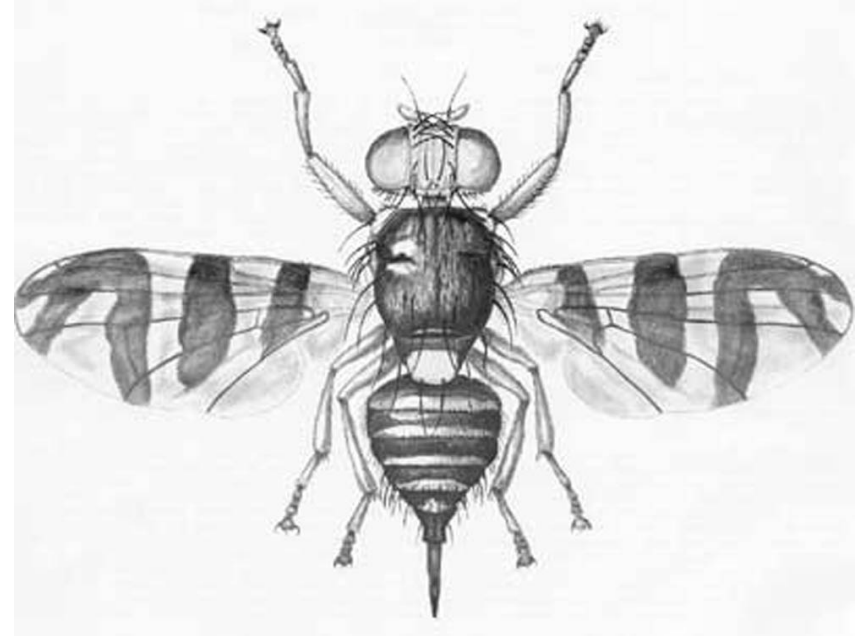

Figure 2. Adult female apple maggot fly, Rhagoletis pomonella (Walsh). Credits: Division of Plant Industry

(Prunus spp.), Chickasaw plum (Prunus angutifolia), peach (Prunus persica), and Siberian crabapple (Malus baccata). Larvae have also be found in pear (Pyrus spp.), but no adults emerged. In New England, the fly uses the hips (fruits) of Japanese rose (Rosa rugosa) and Rosa carolina as alternative hosts. Recently, $R$. pomonella has adapted to attacking sour cherry (Prunus cerasus) in Utah, where it has not been reported from apple (White and Elson-Harris 1994).

\section{Damage}

Injury to fruit is caused by the legless maggots. These maggots bore throughout the fruit, forming irregular, winding tunnels which turn brown, often causing premature dropping of fruit. When the fruit is slightly infested, there may be no external indication of the presence of the maggots, but when the fruit ripens, the burrows show as dark, winding trails beneath the skin. Minute egg punctures and distorted, pitted areas may show on the surface. Heavily infested early varieties of fruit will be reduced to a brown rotten mass filled with the fly larvae.

\section{Management}

\section{Cultural}

The systematic destruction of infested apples and the elimination of hawthorn in the vicinity of orchards are considered valid control practices. Apple maggots in fruits may be killed by placing the fruit in cold storage at $32^{\circ} \mathrm{F}$ for a period of 40 days. 


\section{Biological}

Hymenopterous parasites recorded from $R$. pomonella are a braconid wasp, Opius melleus Gahan, which attacks the larvae, and a tiny mymarid wasp, Patasson conotracheli (Girault), which attacks the eggs. Because the apple maggot feeds within fruit, biological control agents have not been very effective (Elkins 2000).

\section{Chemical}

Consult local university or state recommendations. Emergence and dispersal of adult flies must be carefully monitored to effectively time treatments. Sticky traps, including yellow rectangles and red spheres, are used in other areas to monitor adults and time treatments. Unfortunately, only provisional economic thresholds are available for apple maggots, even in areas where it has long been a pest. You can detect the first emergence of adults by hanging yellow sticky traps in abandoned orchards or unsprayed apple trees in infested areas. To detect the beginning of egg laying, hang red sticky spheres in apple trees, then treat as soon as the first fly is found. In Oregon, where some orchards are now being treated regularly for apple maggots, the first maggot spray is applied 7 to 10 days after the first fly has emerged. Later sprays follow at 10 to 14 day intervals as long as adults are active and are being caught in traps (Elkins 2000).

\section{Selected References}

Beers, E., A.L. Antonelli, and E. LaGasa. (1996). Apple Maggot. Gardening in Western Washington.

http://gardening.wsu.edu/library/tree002/tree002.htm (18 January 2002).

Berkett, L.P. (1984). Apple maggot images. Key Arthropods and Diseases Affecting Apples. http://orchard.uvm.edu/uvmapple/pest/BacktoBasics/ Arthropods/ Apple\%20Maggot\%20Fly.htm\#AMFadult (18 January 2002).

Garman, Philip, and J.F. Townsend. 1952. Control of apple insects. Conn. Agr. Exp. Sta. Bull. $552.84 \mathrm{p}$.
Glass, E.H. 1960. Apple maggot fly emergence in western New York. N.Y. State (Geneva) Agr. Exp. Sta. Bull. 789. 29 p.

Hodson, A.C. 1948. Further studies of lures attractive to the apple maggot. Jour. Econ. Ent. 41: 61-66.

Lathrop, F.H., and C.O. Dirks. 1945. Timing the seasonal cycles of insects: the emergence of Rhagoletis pomonella. Jour. Econ. Ent. 38: 330-334.

White, I.M., and M.M. Elson-Harris. 1994. Fruit Flies of Economic Significance: Their Identification and Bionomics. CAB International. Oxon, UK. 601 p. 